\title{
Tuning Spectral and Electrochemical Properties of Porphyrin-Sensitized Solar Cells
}

\author{
Chen-Fu Lo, ${ }^{\dagger}$ Shun-Ju Hsu, ${ }^{\dagger}$ Chin-Li Wang, ${ }^{\dagger}$ Yi-Hui Cheng, ${ }^{\dagger}$ Hsueh-Pei Lu, ${ }^{\dagger}$ \\ Eric Wei-Guang Diau, ${ }^{*, *}$ and Ching-Yao Lin $*, \dagger$ \\ Department of Applied Chemistry, National Chi Nan University, Puli, Nantou Hsien 545, Taiwan, and \\ Department of Applied Chemistry and Institute for Molecular Science, National Chiao Tung University, \\ Hsinchu 300, Taiwan
}

Received: April 20, 2010; Revised Manuscript Received: May 28, 2010

\begin{abstract}
Phenylethynyl-substituted porphyrin (PE1) sensitizers bearing a nitro, cyano, methoxy, or dimethylamino phenylethynyl substituent were prepared to examine the electron-donating or -withdrawing effects of dyes on the photovoltaic performance of the corresponding dye-sensitized solar cells. The overall efficiencies of power conversion of the devices show a systematic trend $\mathrm{Me}_{2} \mathrm{~N}-\mathrm{PE} 1>\mathrm{MeO}-\mathrm{PE} 1>\mathrm{CN}-\mathrm{PE} 1>\mathrm{NO}_{2}-\mathrm{PE} 1$, for which $\mathrm{Me}_{2} \mathrm{~N}-\mathrm{PE} 1$ has a device performance about $90 \%$ of that of a N719-sensitized solar cell under the same experimental conditions. The superior performance of $\mathrm{Me}_{2} \mathrm{~N}-\mathrm{PE} 1$ is attributed to the effective electron-donating property of the dye that exhibits broadened and red-shifted spectral features. According to frontier orbitals based on DFT calculations, the electrons are effectively injected from the dye to $\mathrm{TiO}_{2}$ for $\mathrm{Me}_{2} \mathrm{~N}-\mathrm{PE} 1$ and MeO-PE1 upon excitation, but that driving force reverses for $\mathrm{NO}_{2}-\mathrm{PE}$. Electrochemical tests indicate that both LUMO and HOMO levels show a systematic trend $\mathrm{Me}_{2} \mathrm{~N}-\mathrm{PE} 1>\mathrm{MeO}-\mathrm{PE} 1>\mathrm{CN}-\mathrm{PE} 1>\mathrm{NO}_{2}-\mathrm{PE} 1$, consistent with the trend of variation of the short-circuit currents in this series of sensitizers.
\end{abstract}

\section{Introduction}

Dye-sensitized solar cells (DSSC) draw much attention. ${ }^{1,2}$ $\mathrm{Ru}(\mathrm{II})$ complexes, such as N3, N719, and C101 dyes, are the most efficient photosensitizers. ${ }^{1 b, 3,4}$ Among dyes under investigation, porphyrins are considered as efficient sensitizers for DSSC applications ${ }^{2 \mathrm{~b}, \mathrm{c}, 5-10}$ because of their strong absorption in the visible region. ${ }^{11}$ For example, Officer and co-workers reported a porphyrin-sensitized solar cell that reached an overall efficiency $\eta=7.1 \% .^{5}$ Yeh and co-workers found that a porphyrin-based SC outperforms a Ru-complex-based SC with no added scattering layer. ${ }^{6 \mathrm{~b}}$ Our previous work on zinc porphyrins with phenylethynyl (PE) links of varied lengths (PE1-PE4) showed that the porphyrins with shorter links (PE1 and PE2) outperform those with longer links (PE3 and PE4). ${ }^{9}$ Based on a structure similar to PE2, we further incorporated acene groups in the bridge between the porphyrin core and the anchoring group $(-\mathrm{COOH})$ to improve the light-harvesting ability, increasing the overall efficiency of the device with anthracene substituent to $5.44 \% .^{10}$ In the present work, we explore the possibility of improving the photovoltaic performance of PE1-sensitized solar cells by tuning the spectral and electrochemical characteristics of the sensitizers with added electron-withdrawing or -donating groups. As shown in Chart 1 , the new porphyrins (denoted as X-PE1) are based on the molecular structure of PE1 with additional 4-dimethylamino $\left(\mathrm{Me}_{2} \mathrm{~N}-\mathrm{PE} 1\right)$, 4-methoxy (MeO-PE1), 4-cyano (CN-PE1), or 4-nitro $\left(\mathrm{NO}_{2}\right.$-PE1) phenylethynyl groups in the meso position opposite the anchoring group. Using electron-donating or -withdrawing groups to tune the photophysical properties of a porphyrin is well documented by Therien and co-workers. ${ }^{12} \mathrm{~A}$ theoretical screening by Grätzel and co-workers showed that

* To whom correspondence should be addressed. E-mail: cyl@ncnu.edu.tw (C.-Y.L.); diau@mail.nctu.edu.tw (E.W.-G.D.).

National Chi Nan University.

* National Chiao Tung University.
CHART 1: Molecular Structures of PE1 and X-PE1 Porphyrins

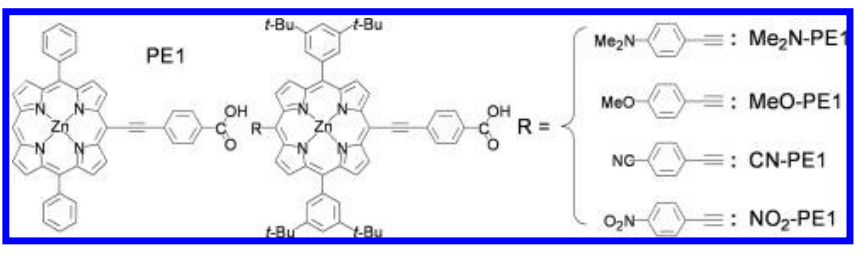

preparing porphyrin sensitizers in a suitable donor-acceptor fashion might create a highly efficient porphyrin sensitizer. ${ }^{13}$ Here we report the preparation, absorption and fluorescence spectra, quantum-chemical calculations, electrochemical properties, and photovoltaic performance for X-PE1 porphyrin sensitizers. We found that the performance of the $\mathrm{Me}_{2} \mathrm{~N}-\mathrm{PE} 1$ device reached $\eta=6.12 \%$, which is $\sim 90 \%$ of the N719-based SC under the same experimental conditions.

\section{Results and Discussion}

Molecular Design and Synthesis. Details of the synthetic procedure and compound characterization are described in the Supporting Information. In brief, the standard Sonogashira crosscoupling method was employed to prepare X-PE1 porphyrins. ${ }^{14}$ The substituents, namely 4-nitrophenylethyne, 4-cyanophenylethyne, 4-methoxyphenylethyne, and 4-ethynylbenzoic acid, were prepared according to the literature methods. ${ }^{9,12 b, 14-17}$ For $\mathrm{X}-\mathrm{PE} 1$ porphyrins, zinc porphine acts as the primary chromophore. 3,5-Di-tert-butyl-phenyl groups serve to increase the solubility, to lessen aggregation, and to protect the porphine core structure. 4-Dimethylaminophenyl, 4-methoxyphenyl, 4-cyanophenyl, and 4-nitrophenyl groups are employed to represent substituents with varied electron-donating or -withdrawing properties. The advantage of this design is that all X-PE1 porphyrins can be prepared in two steps from a brominated porphyrin. 


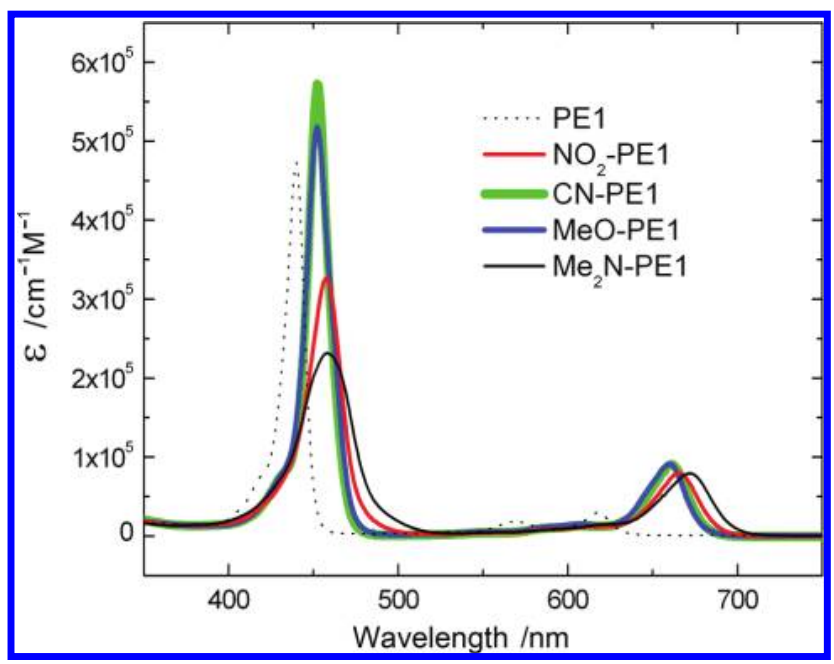

Figure 1. UV-visible absorption spectra of PE1 and X-PE1 porphyrins in THF.

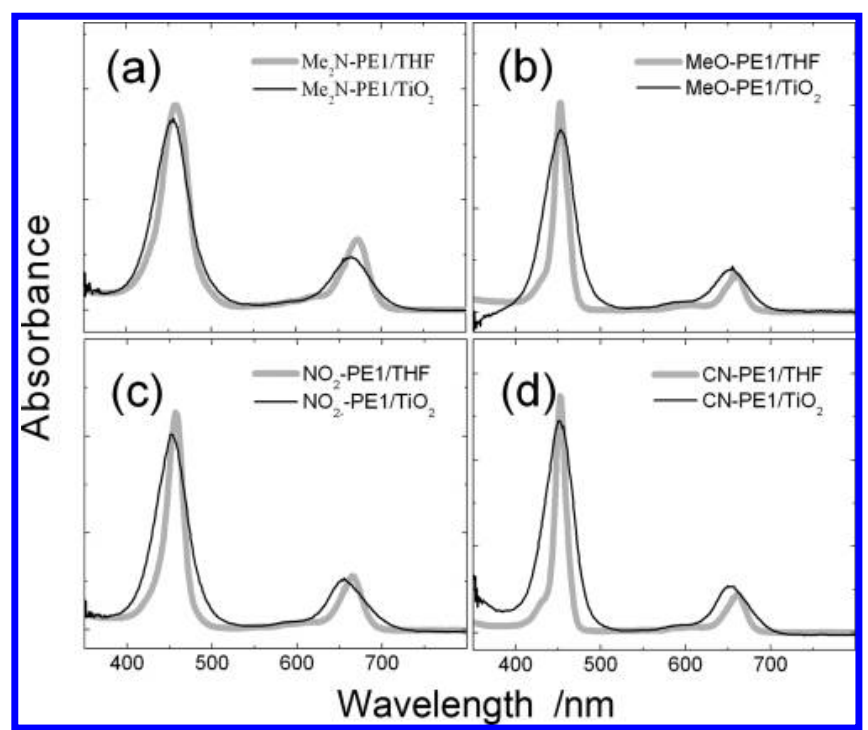

Figure 2. UV-visible absorption spectra of (a) $\mathrm{Me}_{2} \mathrm{~N}-\mathrm{PE} 1$, (b) MeO$\mathrm{PE} 1$, (c) $\mathrm{NO}_{2}$-PE1, and (d) CN-PE1 porphyrins in THF (gray traces) and on $\mathrm{TiO}_{2}$ films in air (black traces).

UV-Visible Absorption and Fluorescence Spectra. Figure 1 shows UV-visible spectra of PE1 and X-PE1 porphyrins in THF. Figure 2 compares the UV-visible spectra of X-PE1 porphyrins in THF and those on $\mathrm{TiO}_{2}$ films. Figure 3 shows fluorescence spectra of X-PE1 porphyrins in THF. The peak wavelengths of the UV-visible absorption and fluorescence spectra are collected in Table 1.

As shown in Figure 1, PE1 and X-PE1 porphyrins exhibit typical porphyrin absorption characteristics: ${ }^{11}$ Strong B (Soret) bands are found in the higher energy region, whereas weaker Q bands are observed in the lower energy region. Upon incorporating the arylethynes into the $\pi$-conjugation system of PE1, the B bands red shift from $440 \mathrm{~nm}$ to $458,452,452$, and $458 \mathrm{~nm}$ for $\mathrm{Me}_{2} \mathrm{~N}-\mathrm{PE} 1, \mathrm{MeO}-\mathrm{PE} 1, \mathrm{CN}-\mathrm{PE} 1$, and $\mathrm{NO}_{2}$-PE1, respectively (Table 1). A similar pattern is observed for the $\mathrm{Q}$ bands: the $\mathrm{Q}(0,0)$ bands red shift from $618 \mathrm{~nm}$ for PE1 to 672 , 660,661 , and $665 \mathrm{~nm}$ for $\mathrm{Me}_{2} \mathrm{~N}-\mathrm{PE} 1, \mathrm{MeO}-\mathrm{PE} 1, \mathrm{CN}-\mathrm{PE} 1$, and $\mathrm{NO}_{2}-\mathrm{PE} 1$, respectively. These spectral shifts are consistent with literature reports, ${ }^{12}$ indicating that the $\pi$-conjugation of X-PE1 porphyrins becomes extended. Among X-PE1 porphyrins, the absorption bands of $\mathrm{Me}_{2} \mathrm{~N}-\mathrm{PE} 1$ and $\mathrm{NO}_{2}$-PE1 are more red shifted and broadened than those of CN-PE1 and MeO-PE1.

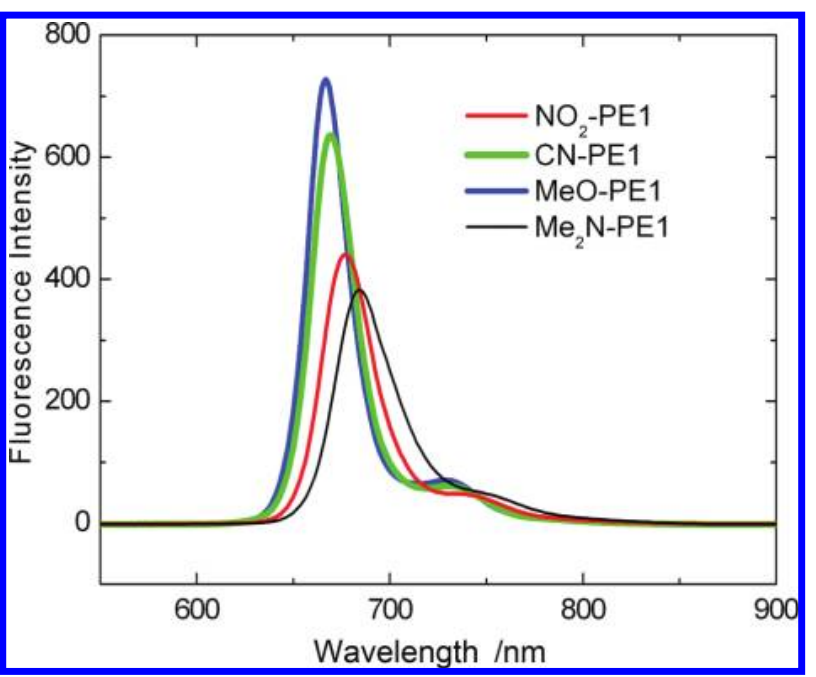

Figure 3. Fluorescence spectra of X-PE1 porphyrins in THF. Experimental conditions: [X-PE1] $=2 \times 10^{-6} \mathrm{M}$. Excitation wavelength/ nm: $\mathrm{Me}_{2} \mathrm{~N}-\mathrm{PE} 1,458$; MeO-PE1, 452; CN-PE1, 452; and $\mathrm{NO}_{2}-\mathrm{PE} 1$, 458.

TABLE 1: UV-Visible Absorption and Fluorescence ${ }^{a}$ Maxima of PE1 and X-PE1 Porphyrins in THF

\begin{tabular}{lll}
\hline \multicolumn{1}{c}{ dye } & \multicolumn{1}{c}{$\begin{array}{c}\text { absorption/nm } \\
\left(\log \varepsilon, 10^{5} \mathrm{M}^{-1} \mathrm{~cm}^{-1}\right)\end{array}$} & emission/nm \\
\hline PE1 & $440(5.67), 569(4.25), 618(4.47)$ & 622,676 \\
$\mathrm{Me}_{2} \mathrm{~N}-\mathrm{PE} 1$ & $458(5.36), 672(4.89)$ & 683 \\
$\mathrm{MeO}-\mathrm{PE} 1$ & $452(5.70), 660(4.95)$ & 666 \\
$\mathrm{CN}-\mathrm{PE} 1$ & $452(5.75), 661(4.95)$ & 668 \\
$\mathrm{NO}_{2}$-PE1 & $458(5.51), 665(4.90)$ & 677
\end{tabular}

${ }^{a}$ Excitation wavelength/nm: PE1, 440; $\mathrm{Me}_{2} \mathrm{~N}-\mathrm{PE} 1, \quad 458$; MeO-PE1, 452; CN-PE1, 452; and $\mathrm{NO}_{2}$-PE1, 458.

This condition conforms to the fact that $\mathrm{Me}_{2} \mathrm{~N}-$ and $\mathrm{NO}_{2}$ phenylethynes are the stronger electron-donating and electronwithdrawing substituents among the four substituents under investigation.

Figure 2 compares the absorption spectra of X-PE1 in THF and those on $\mathrm{TiO}_{2}$ films. To present both $\mathrm{B}$ and $\mathrm{Q}$ bands in these spectra, only small amounts of the porphyrins were allowed to adsorb onto $\mathrm{TiO}_{2}$ films (i.e., the films were partially loaded); in addition, the intensities of the absorption bands are rescaled to fit two spectra in one figure. Comparison of the film and solution spectra reveals that the $\mathrm{B}$ and $\mathrm{Q}$ bands of the $\mathrm{X}-\mathrm{PE} 1 / \mathrm{TiO}_{2}$ films are only slightly shifted but considerably broadened from those of the solution spectra. The broadened absorption bands of the thin-film samples might reflect intermolecular interactions of molecules aggregated on the $\mathrm{TiO}_{2}$ surfaces. The feature of the blue shoulders of $\mathrm{B}$ bands previously observed for porphyrins in the $\mathrm{PEx}^{9}$ and $\mathrm{LAC}^{10}$ series is not noticeable in the X-PE1 film spectra. As these blue shoulders represent $\mathrm{H}$-type aggregation of porphyrins on surfaces of $\mathrm{TiO}_{2}$ nanoparticles, the lack of such shoulders indicates that $\mathrm{H}$-type aggregation of X-PE1 on $\mathrm{TiO}_{2}$ might become suppressed by the 3,5-di-tert-butyl-phenyl groups, especially for $\mathrm{Me}_{2} \mathrm{~N}-\mathrm{PE} 1$.

For the fluorescence spectra (Figure 3), major emission bands of X-PE1 porphyrins were observed at 683, 666, 668, and 677 $\mathrm{nm}$ for $\mathrm{Me}_{2} \mathrm{~N}-\mathrm{PE} 1, \mathrm{MeO}-\mathrm{PE} 1, \mathrm{CN}-\mathrm{PE} 1$, and $\mathrm{NO}_{2}$-PE1, respectively. The trend for the X-PE1 emissions red shifted from that of PE1 is similar to the trend of the Q-band absorption spectra with the order of the peak wavelength $\mathrm{Me}_{2} \mathrm{~N}-\mathrm{PE} 1>\mathrm{NO}_{2}-\mathrm{PE} 1$ $>\mathrm{CN}$-PE1 $\sim \mathrm{MeO}-\mathrm{PE} 1$. The intensities of the fluorescence bands are comparable among all X-PE1 porphyrins. 


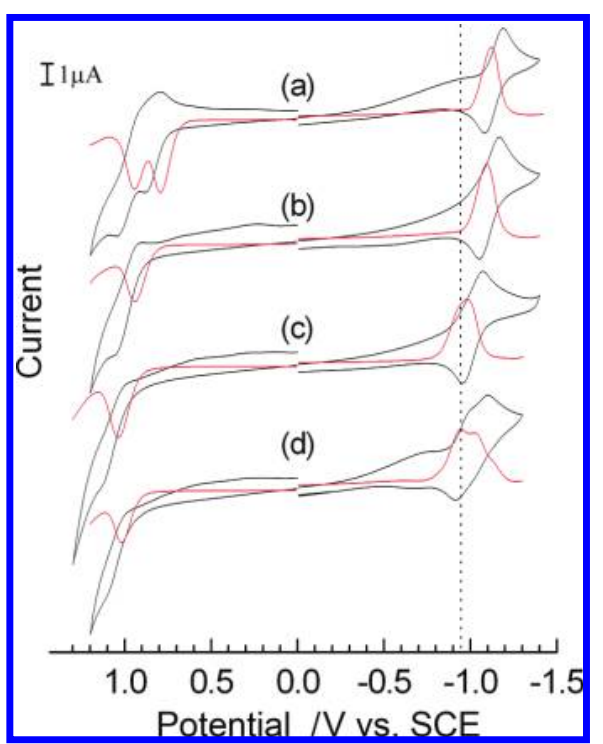

Figure 4. Cyclic voltammograms (black) and differential pulse voltammograms (red) of (a) $\mathrm{Me}_{2} \mathrm{NPE} 1$, (b) MeO-PE1, (c) CN-PE1, and (d) $\mathrm{NO}_{2}$-PE1 (all $0.5 \mathrm{mM}$ in THF/0.1 M TBAP). The dotted line indicates the first porphyrin ring reduction potential of $\mathrm{NO}_{2}-\mathrm{PE} 1$.

TABLE 2: Potentials of X-PE1 Porphyrins in THF ${ }^{a}$

\begin{tabular}{clllll}
\hline & & \multicolumn{4}{c}{ V vs SCE } \\
\cline { 3 - 5 } \multicolumn{1}{c}{ dye } & & Ox(2) & Ox(1) & $\operatorname{Red}(1)$ & $\operatorname{Red}(2)$ \\
\hline $\mathrm{Me}_{2} \mathrm{~N}-\mathrm{PE} 1$ & $\mathrm{DPV}^{b}$ & +0.94 & +0.80 & -1.12 \\
& $\mathrm{CV}^{c}$ & $+0.98(130)$ & $+0.84(90)$ & $-1.14(110)$ \\
$\mathrm{MeO}-\mathrm{PE} 1$ & $\mathrm{DPV}$ & & +0.94 & -1.09 & \\
& $\mathrm{CV}$ & $+0.98(150)$ & $-1.11(120)$ \\
$\mathrm{CN}-\mathrm{PE} 1$ & $\mathrm{DPV}$ & +1.04 & -0.98 & \\
& $\mathrm{CV}$ & & $+1.06(150)$ & $-1.01(110)$ \\
$\mathrm{NO}_{2}$-PE1 & $\mathrm{DPV}$ & & +1.02 & -0.94 & -1.03 \\
& $\mathrm{CV}$ & & $+1.04(120)$ & $-0.96(90)$ & $-1.05(90)$
\end{tabular}

${ }^{a}$ Experimental conditions: X-PE1 $(0.5 \mathrm{mM})$ in THF/0.1 M TBAP under $\mathrm{N}_{2}$ near $296 \mathrm{~K}$; Pt working and counter electrodes; SCE reference electrode; scan rate $=100 \mathrm{mV} / \mathrm{s}$. For ferrocene/forrocenium $\left(\mathrm{Fc} / \mathrm{Fc}^{+}\right)$in the same conditions, $E_{1 / 2}=+0.49 \mathrm{~V}$ vs SCE. ${ }^{b} \mathrm{DPV}$, differential pulse voltammetry. ${ }^{c} \mathrm{CV}$, cyclic voltammetry. Peak-to-peak separations (in $\mathrm{mV}$ ) appear in parentheses for quasi-reversible reactions.

Electrochemical Properties and Density Functional Theory (DFT) Calculations. Figure 4 overlays the cyclic voltammograms (CVs) and differential pulse voltammograms (DPVs) of $\mathrm{X}$-PE1 porphyrins in THF/TBAP; the potentials of X-PE1 porphyrins are collected in Table 2. Differential pulse voltammetry was employed to improve the resolution of the overlapping oxidation and reduction waves, in particular for $\mathrm{Me}_{2} \mathrm{~N}$ PE1 and $\mathrm{NO}_{2}-\mathrm{PE} 1$.

The first porphyrin ring reductions of X-PE1 are found at $-1.12,-1.09,-0.98$, and $-0.94 \mathrm{~V}$ vs SCE as quasi-reversible reactions for $\mathrm{Me}_{2} \mathrm{~N}-\mathrm{PE} 1, \mathrm{MeO}-\mathrm{PE} 1, \mathrm{CN}-\mathrm{PE} 1$, and $\mathrm{NO}_{2}-\mathrm{PE} 1$, respectively. These values are consistent with a literature report of porphyrins with similar substituents. ${ }^{12 \mathrm{a}}$ These potentials are positively shifted from that of PE1 porphyrin $(-1.23 \mathrm{~V}$ vs SCE), ${ }^{9 a}$ indicating the effect of extended $\pi$-conjugation. The ease of reduction of the series has the order $\mathrm{NO}_{2}-\mathrm{PE} 1>\mathrm{CN}-$ PE1 > MeO-PE1 > Me 2 N-PE1. This trend is consistent with the electron-donating or -withdrawing abilities of each arylethynyl substituent. One further reduction was observed for $\mathrm{NO}_{2}{ }^{-}$ PE1 at $-1.03 \mathrm{~V}$ vs SCE. Comparison of the CV and DPV of $\mathrm{NO}_{2}$-PE1 and those of $\mathrm{NO}_{2}$-phenylethyne indicates that this more negative reduction is localized at the $\mathrm{NO}_{2}$ substituent (Figure S5, Supporting Information). The broad features before the first porphyrin ring reductions of X-PE1 are reductions of anchoring substituents as previously described. ${ }^{9 a}$

For oxidation reactions, two overlapped quasi-reversible redox couples were observed for $\mathrm{Me}_{2} \mathrm{~N}-\mathrm{PE} 1$ at +0.80 and $+0.94 \mathrm{~V}$ vs SCE. Only one redox couple was observed at $+0.94,+1.04$, and $+1.02 \mathrm{~V}$ vs SCE for MeO-PE1, CN-PE1, and $\mathrm{NO}_{2}-\mathrm{PE} 1$, respectively. The oxidations of $\mathrm{CN}-\mathrm{PE} 1$ and $\mathrm{NO}_{2}-\mathrm{PE} 1$ were less reversible than those of $\mathrm{Me}_{2} \mathrm{~N}-\mathrm{PE} 1$ and $\mathrm{MeO}-\mathrm{PE} 1$. The first oxidations are assigned to be porphyrin ring oxidations; these values are consistent with a literature report. ${ }^{12 a}$ The ease of oxidation of the porphyrins has the order $\mathrm{Me}_{2} \mathrm{~N}-\mathrm{PE} 1>\mathrm{MeO}-$ PE1 $>$ CN-PE1 $\sim \mathrm{NO}_{2}$-PE1. The second oxidation of $\mathrm{Me}_{2} \mathrm{~N}-$ $\mathrm{PE} 1$ is suggested to be the oxidation of the $\mathrm{Me}_{2} \mathrm{~N}$ substituent from a comparison of the CVs and DPVs (Figure S6, Supporting Information).

To assist our qualitative understanding of the electrochemical behavior of X-PE1 porphyrins, we performed DFT calculations on X-PE1 porphyrins at the B3LYP/LanL2DZ level of theory. ${ }^{18}$ As shown in Figure 5, the molecular orbital (MO) patterns of $\mathrm{X}$-PE1 porphyrin are consistent with those of Gouterman's fourorbital model; ${ }^{11}$ i.e., HOMO-1 and HOMO resemble those of the $\mathrm{a}_{1 \mathrm{u}}$ and $\mathrm{a}_{2 \mathrm{u}}$ orbitals whereas the LUMO and LUMO+1 are similar to those of the $\mathrm{e}_{\mathrm{g}}$ orbitals. ${ }^{11}$ The patterns are also consistent with the suggestion that the first reduction and oxidation of X-PE1 are reactions centered on the porphyrin ring. However, the HOMO and LUMO patterns exhibit a feature with slight delocalization to the anchoring group and the electrondonating or -withdrawing substituents. This minor deviation from Gouterman's four-orbital model is rationalized through a decreased symmetry of the complexes and an extended $\pi$-conjugation of the substituent. This condition is consistent with the potential shifts of X-PE1 relative to PE1 porphyrin. The HOMO pattern of $\mathrm{Me}_{2} \mathrm{~N}-\mathrm{PE} 1$ shows a considerable electron distribution at the $\mathrm{Me}_{2} \mathrm{~N}$ substituent, whereas its LUMO pattern shows an electron distribution at the porphine core and the anchoring group. Because the anchoring group is attached to $\mathrm{TiO}_{2}$, the above MO feature indicates that there exists a driving force for an efficient electron injection from the dye to the surface of $\mathrm{TiO}_{2}$ upon excitation. In contrast, the LUMO pattern of $\mathrm{NO}_{2}-$ PE1 exhibits an electron distribution localized mainly on the $\mathrm{NO}_{2}$ substituent group, so that the photoexcitation provides a driving force in the opposite direction. The $\mathrm{NO}_{2}$ substituent hence pulls the electron in competition with $\mathrm{TiO}_{2}$ for electron injection from the excited state of the dye.

Figure 6 shows an energy-level diagram of the X-PE1 system, comparing the HOMO/LUMO of each porphyrin with the valence band (VB) and conducting band (CB) of $\mathrm{TiO}_{2}$. This diagram is estimated based on our spectral and electrochemical data: the first reduction potentials were used to determine the LUMO levels and the UV-visible and the fluorescence spectra were used to determine the gaps between the HOMO and LUMO levels. ${ }^{1 \mathrm{a}, 9 \mathrm{a}, 10}$ This diagram shows that the LUMO levels of X-PE1 porphyrins become increasingly stabilized as the substituents are varied from the electron-donating $\mathrm{Me}_{2} \mathrm{~N}$ phenylethynyl group to the electron-withdrawing $\mathrm{NO}_{2}$-phenylethynyl group. Although the LUMO level of $\mathrm{NO}_{2}-\mathrm{PE} 1$ is the least in the series, it is still above the $\mathrm{CB}$ level of $\mathrm{TiO}_{2}$. This condition indicates that (i) LUMO levels of X-PE1 porphyrins should all be capable of injecting electrons to the $\mathrm{CB}$ of $\mathrm{TiO}_{2}$, and (ii) electron injection from the dye to $\mathrm{TiO}_{2}$ might be more favorable for $\mathrm{Me}_{2} \mathrm{~N}-\mathrm{PE} 1$ than for $\mathrm{NO}_{2} \mathrm{PE} 1$.

Photovoltaic Properties. Parts a and b of Figure 7 show the spectra for the efficiency of conversion of an incident photon to current (IPCE) and the corresponding current-voltage curves 


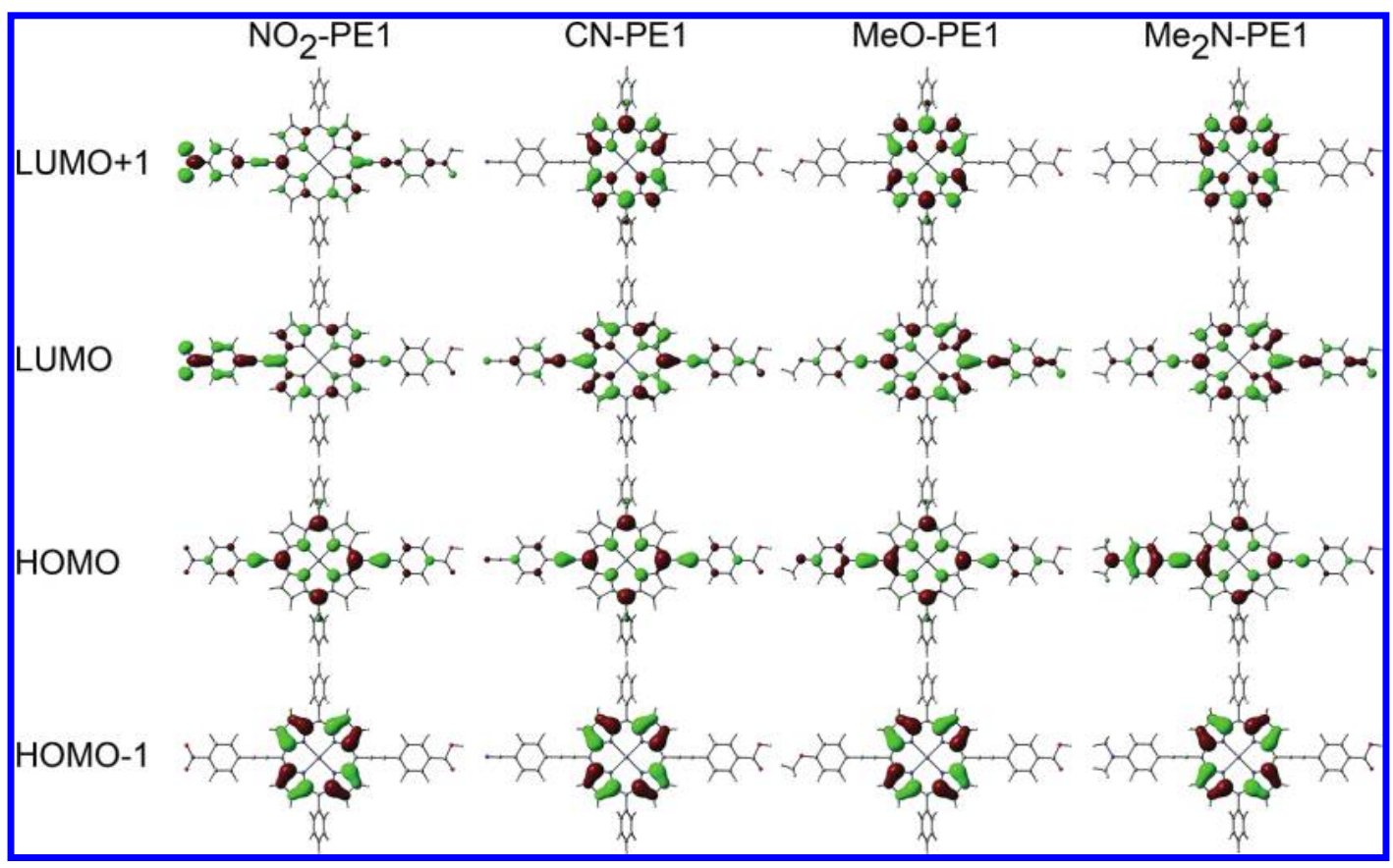

Figure 5. Molecular orbital patterns of X-PE1 porphyrins with geometries of each molecule optimized at the B3LYP/LanL2DZ level of theory. These MO patterns serve to assist qualitatively our understanding of the porphyrins.

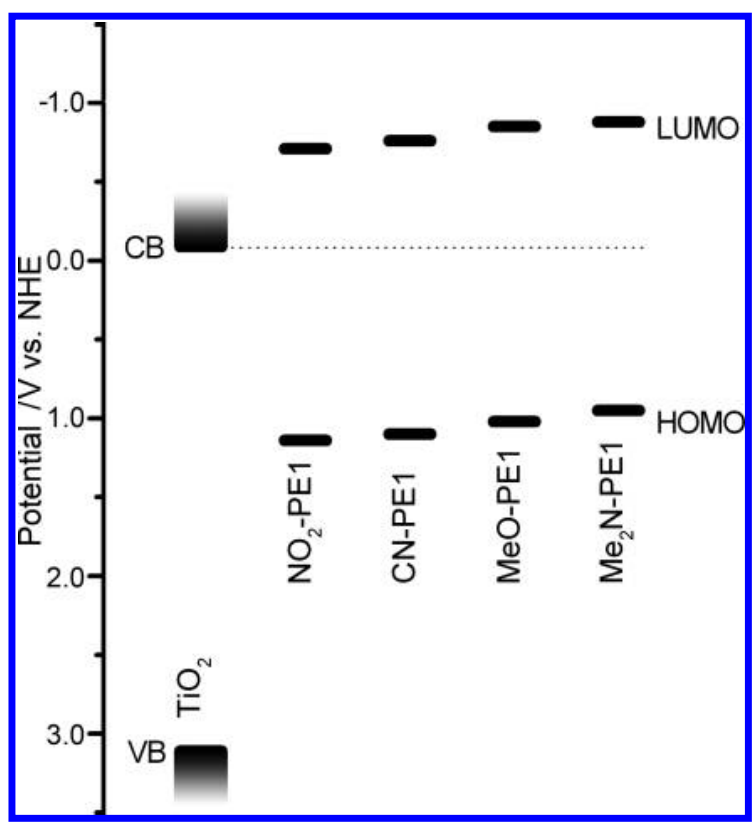

Figure 6. Energy-level diagram of X-PE1 porphyrins and $\mathrm{TiO}_{2}$.

for each dye under investigation, respectively. To demonstrate the reproducibility of the data, three independent measurements were performed for each dye using $\mathrm{TiO}_{2}$ films fabricated with an identical procedure; the corresponding averaged photovoltaic parameters are listed in Table 3 . The overall efficiencies of the devices display a systematic trend of increase from $\mathrm{NO}_{2}$-PE1 (1.09\%), CN-PE1 (4.05\%), MeO-PE1 (4.76\%), to $\mathrm{Me}_{2} \mathrm{~N}-\mathrm{PE} 1$ $(6.12 \%)$. In particular, $\mathrm{Me}_{2} \mathrm{~N}-\mathrm{PE} 1$ is the most efficient dye in the series and the corresponding device has reached $90 \%$ of the cell performance of a N719-sensitized solar cell $(7.03 \%)$ fabricated under the same experimental conditions.

The variation of the overall efficiencies of power conversion of the system is consistent with their variation of short-circuit current density $\left(J_{\mathrm{SC}}\right.$, Figure $\left.7 \mathrm{a}\right)$. The IPCE spectra mimic the corresponding UV-visible spectra but with broader features.
The two major responses of the IPCE spectra represent the energy conversion of the porphyrin $\mathrm{B}$ and $\mathrm{Q}$ bands with maximum efficiencies above $60 \%$ for the $\mathrm{Me}_{2} \mathrm{~N}-\mathrm{PE} 1$, MeO$\mathrm{PE} 1$, and $\mathrm{CN}-\mathrm{PE} 1$ devices, but the efficiencies of the $\mathrm{NO}_{2}-\mathrm{PE} 1$ device are significantly smaller. The IPCE responses increase as the electron-donating abilities increase from $\mathrm{NO}_{2}, \mathrm{CN}, \mathrm{MeO}$, to $\mathrm{Me}_{2} \mathrm{~N}$ substituents. Both $\mathrm{B}$ and $\mathrm{Q}$ bands of the IPCE spectrum of the $\mathrm{Me}_{2} \mathrm{~N}-\mathrm{PE} 1$ device are significantly broader than those of the other porphyrin devices, especially in the regions 500-550 and $700-750 \mathrm{~nm}$. As a result, the greater light-harvesting ability of $\mathrm{Me}_{2} \mathrm{~N}-\mathrm{PE} 1$ contributes the larger $J_{\mathrm{SC}}$ value of the SC (13.08 $\mathrm{mA} \mathrm{cm}{ }^{-2}$ ). The greater efficiencies of $\mathrm{Me}_{2} \mathrm{~N}-\mathrm{PE} 1$ are also attributed to the greater efficiency of electron injection as predicted by the driving force to give an efficient electron injection inferred from the electron distribution of the frontier orbitals aforementioned. An electron-donating group such as $\mathrm{Me}_{2} \mathrm{~N}$ substituent hence facilitates an electron injection from the dye to $\mathrm{TiO}_{2}$, whereas an electron-withdrawing group such as $\mathrm{NO}_{2}$ substituent obstructs that function to deteriorate the cell performance.

The molecular structure of $\mathrm{Me}_{2} \mathrm{~N}-\mathrm{PE} 1$ is similar to that of a porphyrin (YD7) reported by Yeh and Diau, ${ }^{6 c}$ but the device performance of $\mathrm{Me}_{2} \mathrm{~N}-\mathrm{PE} 1(6.12 \%)$ is much better than that of YD7 (4.38\%). We note that separate immersing solvents were used for the two systems: the dye soaking of YD7 was made in ethanol whereas that of $\mathrm{Me}_{2} \mathrm{~N}-\mathrm{PE} 1$ was made in THF. Protic solvents might influence the adsorption and geometry of the porphyrins on a $\mathrm{TiO}_{2}$ surface, ${ }^{19}$ and in some cases ${ }^{6,7,19}$ ethanol or methanol is a superior immersing solvent whereas in other cases $^{9,10,20}$ THF is superior. As YD7 does not dissolve well in ethanol, it suffered from the problem of dye aggregation when adsorbed on the $\mathrm{TiO}_{2}$ surface. ${ }^{6 c}$ Because dye aggregation is greatly suppressed in THF (Figure 2a), the IPCE values of $\mathrm{Me}_{2} \mathrm{~N}-\mathrm{PE} 1$ are significantly greater than those of YD7. As for the dye adsorption time, X-PE1 sensitized solar cells with $2 \mathrm{~h}$ of $\mathrm{TiO}_{2}$ immersing time demonstrated the most satisfactory photovoltaic results. We noticed incomplete dye adsorption at a shorter immersing time, and the overall efficiencies of the 


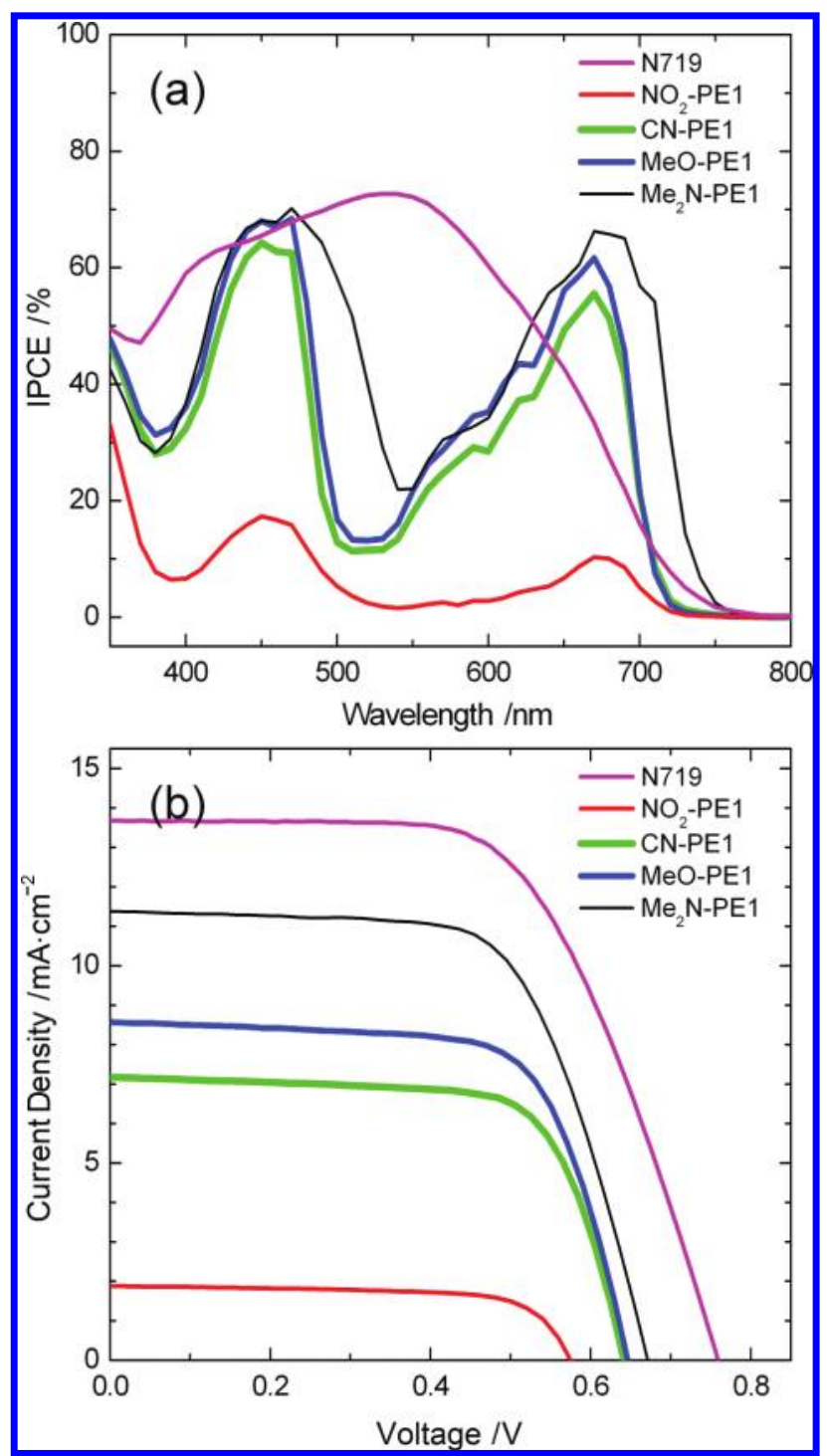

Figure 7. (a) Photocurrent action spectra and (b) $I-V$ curves of X-PE1sensitized solar cells. Corresponding overall efficiencies are $6.89 \%$ for $\mathrm{N} 719,5.67 \%$ for $\mathrm{Me}_{2} \mathrm{~N}-\mathrm{PE} 1,4.20 \%$ for MeO-PE1, $3.68 \%$ for CN$\mathrm{PE} 1$, and $0.84 \%$ for $\mathrm{NO}_{2}$-PE1 in these figures (not a mean value).

TABLE 3: Photovoltaic Parameters of X-PE1-Sensitized Solar Cells ${ }^{a}$

\begin{tabular}{lrccc}
\hline \multicolumn{1}{c}{ dye $^{b}$} & \multicolumn{1}{c}{$J_{\mathrm{SC}} / \mathrm{mA} \mathrm{cm}^{-2}$} & \multicolumn{1}{c}{$V_{\mathrm{OC}} / \mathrm{V}$} & $\mathrm{FF}$ & $\eta / \%$ \\
\hline Me 2 N-PE1 & $13.08 \pm 0.68$ & $0.68 \pm 0.01$ & $0.68 \pm 0.00$ & $6.12 \pm 0.35$ \\
$\mathrm{MeO}-\mathrm{PE} 1$ & $10.13 \pm 0.17$ & $0.56 \pm 0.09$ & $0.69 \pm 0.00$ & $4.76 \pm 0.02$ \\
$\mathrm{CN}-\mathrm{PE} 1$ & $8.59 \pm 0.05$ & $0.65 \pm 0.00$ & $0.72 \pm 0.00$ & $4.05 \pm 0.03$ \\
$\mathrm{NO}_{2}$-PE1 & $2.53 \pm 0.10$ & $0.57 \pm 0.00$ & $0.74 \pm 0.00$ & $1.09 \pm 0.04$ \\
$\mathrm{~N} 719^{c}$ & $13.48 \pm 0.30$ & $0.75 \pm 0.00$ & $0.70 \pm 0.02$ & $7.03 \pm 0.19$
\end{tabular}

${ }^{a}$ Under AM1.5 illumination (power $100 \mathrm{~mW} \mathrm{~cm}^{-2}$ ) with active area $0.16 \mathrm{~cm}^{2}$. Three independent measurements were performed for all dyes using $\mathrm{TiO}_{2}$ films fabricated with an identical procedure to demonstrate the reproducibility of the data (see Supporting Information for the complete table). ${ }^{b}$ Typical dye loads $/ \mathrm{nmol} \mathrm{cm}{ }^{-2}$ of X-PE1-sensitized solar cells are estimated to be 85 for $\mathrm{Me}_{2} \mathrm{~N}-\mathrm{PE} 1,79$ for MeO-PE1, 68 for CN-PE1, and 61 for $\mathrm{NO}_{2}$-PE1. ${ }^{c}$ As a reference, the overall efficiency of a N719- sensitized solar cell was also determined.

solar cells were poorer. On the other hand, prolonged dye adsorption did not yield higher overall efficiencies of the devices. This is consistent with the recent report by Imahori and coworkers. ${ }^{19}$

\section{Conclusions}

To examine the electron-donating/withdrawing effects on the photovoltaic properties of the corresponding porphyrin-sensitized solar cells, we prepared four porphyrins bearing $\mathrm{NO}_{2-}, \mathrm{CN}-$, $\mathrm{MeO}$-, or $\mathrm{Me}_{2} \mathrm{~N}$-phenylethynyl substituents. $\mathrm{Me}_{2} \mathrm{~N}$-PE1 yields the most red-shifted and broadened UV-visible absorption and fluorescence bands in the series. Electrochemical tests show that $\mathrm{Me}_{2} \mathrm{~N}-\mathrm{PE} 1$ is the most easily oxidized whereas $\mathrm{NO}_{2}$-PE1 is the most easily reduced. The combination of both spectral and electrochemical results predicts the potentials of the HOMO and LUMO levels with the order $\mathrm{Me}_{2} \mathrm{~N}-\mathrm{PE} 1>\mathrm{MeO}-\mathrm{PE} 1>\mathrm{CN}-$ $\mathrm{PE} 1>\mathrm{NO}_{2}-\mathrm{PE} 1$. The electron distributions of frontier orbitals predicted with DFT calculations indicate that there exists a driving force for the $\mathrm{Me}_{2} \mathrm{~N}$ substituent to push the electrons toward $\mathrm{TiO}_{2}$ whereas there exists a reverse driving force for the $\mathrm{NO}_{2}$ substituent to pull the electrons in competition with $\mathrm{TiO}_{2}$ for electron injection from the excited state of the dye. As a result, the photovoltaic performances of X-PE1-sensitized solar cells exhibit a systematic trend: $\mathrm{Me}_{2} \mathrm{~N}-\mathrm{PE} 1(6.12 \%)>$ MeO-PE1 $(4.76 \%)>\mathrm{CN}-\mathrm{PE} 1(4.05 \%)>\mathrm{NO}_{2}$-PE1 $(1.09 \%)$. The superior cell performance of $\mathrm{Me}_{2} \mathrm{~N}-\mathrm{PE} 1$ is rationalized to be due to the broader and more red-shifted spectral feature and the more efficient electron-injection ability. Furthermore, the IPCE spectra of X-PE1 sensitizers exhibit a complementary spectral feature compared with those of the Ru-complex sensitizers. Co-sensitization of the two dyes can thus be employed in a tandem solar cell system to enhance further the overall performance.

\section{Experiments}

Materials. Solvents used in the synthesis (ACS grade) were obtained from Mallinckrodt Baker, Inc. $\left(\mathrm{CH}_{2} \mathrm{Cl}_{2}, \mathrm{CHCl}_{3}\right.$, toluene, and ethyl acetate; USA), Haltermann (hexanes; Hamburg, Germany), and Merck (tetrahydrofuran (THF); Darmstadt, Germany). These solvents were used as received unless otherwise stated. Other chemicals, including 4-dimethylethyne, were ordered from Acros Organics (USA). Tetrahydrofuran for synthesis was purified and dried with a solvent-purification system (Asiawong SD-500). Tetrahydrofuran and tetrabutylammonium perchlorate (TBAP) for electrochemical measurements were purified according to literature methods. ${ }^{21} \mathrm{Pd}\left(\mathrm{PPh}_{3}\right)_{4}$ catalyst was purchased from Strem Chemical Inc. (USA). Chromatographic purification was performed with Silica Gel 60 (230-400 mesh, Merck).

Instruments. A glovebox (MBraun Uni-lab), a vacuum line, and standard Schlenk glassware were employed to process all materials sensitive to air. Absorption spectra were recorded (Agilent $8453 \mathrm{UV}$-visible spectrophotometer). Fluorescence spectra were measured (Varian Cary Eclipse fluorescence spectrophotometer). NMR data were recorded (Varian Unity Inova 300WB NMR spectrometer). Elemental analyses were performed (Elementar Vario EL III, NSC Instrumentation Center at National Chung Hsing University). Mass spectra were recorded (Microfilex MALDI-TOF MS, Bruker Daltonics). Cyclic voltammograms (CH Instruments Electrochemical Workstation 611A) were recorded with a standard three-electrode cell (Pt working electrode, $\mathrm{Pt}$ auxiliary electrode, and SCE reference electrode).

Cell Fabrication and Performance Characterization. The porphyrin-based DSSC devices were fabricated with a $\mathrm{TiO}_{2}$ nanoparticulated working electrode and a Pt-coated counter electrode. For a working electrode, a $\mathrm{TiO}_{2}$ nanoparticulate film was produced on a fluoride-doped tin oxide (FTO, $30 \Omega / \square$, Sinonar, Taiwan) glass via screen printing. Crystallization of 
$\mathrm{TiO}_{2}$ films (thickness $\sim 12 \mu \mathrm{m}$ and active area $0.16 \mathrm{~cm}^{2}$ ) was performed with annealing in two stages: heating at $450{ }^{\circ} \mathrm{C}$ for 5 min followed by heating at $500{ }^{\circ} \mathrm{C}$ for $30 \mathrm{~min}$. The electrode was then immersed in a porphyrin/THF solution $(0.2 \mathrm{mM}, 25$ ${ }^{\circ} \mathrm{C}, 2 \mathrm{~h}$ ) containing chenodeoxycholic acid (CDCA; $0.2 \mathrm{mM}$ ) for dye loading onto the $\mathrm{TiO}_{2}$ film. The Pt counter electrodes were prepared on spin-coating drops of $\mathrm{H}_{2} \mathrm{PtCl}_{6}$ solution onto FTO glass and heating at $400{ }^{\circ} \mathrm{C}$ for $15 \mathrm{~min}$. To prevent a short circuit, the two electrodes were assembled into a cell of sandwich type and sealed with a hot-melt film (SX1170, Solaronix, thickness $25 \mu \mathrm{m}$ ). The electrolyte solution containing LiI (0.1 M), I 2 (0.05 M), PMII (0.6 M), and 4-tert-butylpyridine $(0.5 \mathrm{M})$ in a mixture of acetonitrile and valeronitrile (volume ratio 85:15) was introduced into the space between the two electrodes, so completing the fabrication of these DSSC devices. The performance of a DSSC device was assessed on measurement of an $I-V$ curve with an AM1.5 solar simulator (NewportOriel 91160), calibrated with a Si-based reference cell (S1133, Hamamatsu) containing an IR-cut filter (KG5) to correct the spectral mismatch of the lamp. Three independent measurements were performed for all dyes using $\mathrm{TiO}_{2}$ films fabricated with an identical procedure to demonstrate the reproducibility of the data.

Acknowledgment. The National Science Council (C.-Y.L., NSC 97-2113-M-260-007-MY2 and NSC 97-2627-M-260-001; E.W.-G.D., NSC98-2113-M-009-014) provided support. We are also grateful to the National Center for High-performance Computing (Taiwan) for the computer time and facilities.

Supporting Information Available: Synthesis and characterization of X-PE1 porphyrins, $\mathrm{CV}$ and DPV of $\mathrm{NO}_{2^{-}}$and $\mathrm{Me}_{2} \mathrm{~N}-\mathrm{PE} 1$ vs $\mathrm{NO}_{2}$ and $\mathrm{Me}_{2} \mathrm{~N}$ substituents, and detailed photovoltaic parameters of X-PE1-sensitized solar cells. This material is available free of charge via the Internet at http:// pubs.acs.org.

\section{References and Notes}

(1) (a) O'Regan, B.; Grätzel, M. Nature 1991, 353, 737-740. (b) Wang, Q.; Ito, S.; Grätzel, M.; Fabregat-Santiago, F.; Mora-Seró, I.; Bisquert, J.; Bessho, T.; Imai, H. J. Phvs. Chem. B 2006, 110, 25210-25221. (c) Grätzel, M. Inorg. Chem. 2005, 44, 6841-6851.

(2) For recent reviews: (a) Grätzel, M. Nature 2001, 414, 338-344. (b) Campbell, W. M.; Burrell, A. K.; Officer, D. L.; Jolley, K. W. Coord. Chem. Rev. 2004, 248, 1363-1379. (c) Imahori, H.; Umeyama, T.; Ito, S. Acc. Chem. Res. 2009, 42, 1809-1818.

(3) Nazeeruddin, M. K.; De Angelis, F.; Fantacci, S.; Selloni, A.; Viscardi, G.; Liska, P.; Ito, S.; Takeru, B.; Grätzel, M. J. Am. Chem. Soc. 2005, 127, 16835-16847.

(4) Gao, F.; Wang, Y.; Shi, D.; Zhang, J.; Wang, M.; Jing, X.; Humphry-Baker, R.; Wang, P.; Zakeeruddin, S. M.; Grätzel, M. J. Am. Chem. Soc. 2008, 130, 10720-10728.

(5) Campbell, W. M.; Jolley, K. W.; Wagner, P.; Wagner, K.; Walsh, P. J.; Gordon, K. C.; Schmidt-Mende, L.; Nazeeruddin, M. K.; Wang, Q.; Grätzel, M.; Officer, D. L. J. Phvs. Chem. C 2007, 111, 11760-11762.
(6) (a) Lee, C.-W.; Lu, H.-P.; Lan, C.-M.; Huang, Y.-L.; Liang, Y.R.; Yen, W.-N.; Liu, Y.-C.; Lin, Y.-S.; Diau, E. W.-G.; Yeh, C.-Y. Chem.-Eur. J. 2009, 15, 1403-1412. (b) Lu, H.-P.; Mai, C.-L.; Tsia, C.Y.; Hsu, S.-J.; Hsieh, C.-P.; Chiu, C.-L.; Yeh, C.-Y.; Diau, E. W.-G. Phvs. Chem. Chem. Phys. 2009, 11, 10270-10274. (c) Hsieh, C.-P.; Lu, H.-P.; Chiu, C.-L.; Lee, C.-W.; Mai, C.-L.; Yen, W.-N.; Hsu, S.-J.; Diau, E. W.G.; Yeh, C.-Y. J. Mater. Chem. 2010, 20, 1127-1134.

(7) (a) Eu, S.; Hayashi, S.; Umeyama, T.; Matano, Y.; Araki, Y.; Imahori, H. J. Phys. Chem. C 2008, 112, 4396-4405. (b) Hayashi, S.; Tanaka, M.; Hayashi, H.; Eu, S.; Umeyama, T.; Matano, Y.; Araki, Y.; Imahori, H. J. Phys. Chem. C 2008, 112, 15576-15585.

(8) (a) Rochford, J.; Chu, D.; Hagfeldt, A.; Galoppini, E. J. Am. Chem. Soc. 2007, 129, 4655-4665. (b) Park, J. K.; Lee, H. R.; Chen, J.; Shinokubo, H.; Osuka, A.; Kim, D. J. Phys. Chem. C 2008, 112, 16691-16699.

(9) (a) Lin, C.-Y.; Lo, C.-F.; Luo, L.; Lu, H.-P.; Hung, C.-S.; Diau, E. W.-G. J. Phys. Chem. C 2009, 113, 755-764. (b) Lo, C.-F.; Luo, L.; Diau, E. W.-G.; Chang, I.-J.; Lin, C.-Y. Chem. Commun. 2006, 1430-1432. (c) Luo, L.; Lin, C.-J.; Tsai, C.-Y.; Wu, H.-P.; Li, L.-L.; Lo, C.-F.; Lin, C.-Y.; Diau, E. W.-G. Phvs. Chem. Chem. Phvs. 2010, 12, 1064-1071. (d) Lin, C.-Y.; Wang, Y.-C.; Hsu, S.-J.; Lo, C.-F.; Diau, E. W.-G. J.Phvs. Chem. C 2010, 114, 687-693.

(10) Lin, C.-Y.; Wang, Y.-C.; Hsu, S.-J.; Lo, C.-F.; Diau, E. W.-G. J. Phvs. Chem. C 2010, 114, 687-693.

(11) Gouterman, M. J. Mol. Spectrosc. 1961, 6, 138.

(12) (a) LeCours, S. M.; DiMagno, S. G.; Therien, M. J. J. Am. Chem. Soc. 1996, 118, 11854-11864. (b) LeCours, S. M.; Guan, H. W.; DiMagno, S. G.; Wang, C. H.; Therien, M. J. J. Am. Chem. Soc. 1996, 118, 14971503. (c) LeCours, S. M.; Philips, C. M.; Paula, J. C. D.; Therien, M. J. J. Am. Chem. Soc. 1997, 119, 12578-12589.

(13) Ma, R.; Guo, P.; Cui, H.; Zhang, X.; Nazeeruddin, M. K.; Grätzel, M. J. Phvs. Chem. A 2009, 113, 10119-10124.

(14) (a) Sonogashira, K.; Tohda, Y.; Hagihara, N. Tetrahedron Lett. 1975, 4467-4470. (b) Takahashi, S.; Kuroyama, Y.; Sonogashira, K. Synthesis 1980, 627-630. (c) Westmijze, H.; Vermeer, P. Synthesis 1979, 390-392. (d) Mesnard, D.; Bernadou, F.; Miginiac, L. J. Chem. Res. 1981, 270-271.

(15) Miki, Y.; Momotake, A.; Arai, T. Org. Biomol. Chem. 2003, 1, 2655-2660

(16) Ranganathan, A.; Heisen, B. C.; Dix, I.; Meyer, F. Chem. Commun. 2007, 3637-3639.

(17) Njus, J. M.; Sandman, D. J. Macromolecules 2005, 38, 7645-7652.

(18) Frisch, M. J.; Trucks, G. W.; Schlegel, H. B.; Scuseria, G. E.; Robb, M. A.; Cheeseman, J. R.; Montgomery, J. A., Jr.; Vreven, T.; Kudin, K. N.; Burant, J. C.; Millam, J. M.; Iyengar, S. S.; Tomasi, J.; Barone, V.; Mennucci, B.; Cossi, M.; Scalmani, G.; Rega, N.; Petersson, G. A.; Nakatsuji, H.; Hada, M.; Ehara, M.; Toyota, K.; Fukuda, R.; Hasegawa, J.; Ishida, M.; Nakajima, T.; Honda, Y.; Kitao, O.; Nakai, H.; Klene, M.; Li, X.; Knox, J. E.; Hratchian, H. P.; Cross, J. B.; Adamo, C.; Jaramillo, J.; Gomperts, R.; Stratmann, R. E.; Yazyev, O.; Austin, A. J.; Cammi, R.; Pomelli, C.; Ochterski, J. W.; Ayala, P. Y.; Morokuma, K.; Voth, G. A.; Salvador, P.; Dannenberg, J. J.; Zakrzewski, V. G.; Dapprich, S.; Daniels, A. D.; Strain, M. C.; Farkas, O.; Malick, D. K.; Rabuck, A. D.; Raghavachari, K.; Foresman, J. B.; Ortiz, J. V.; Cui, Q.; Baboul, A. G.; Clifford, S.; Cioslowski, J.; Stefanov, B. B.; Liu, G.; Liashenko, A.; Piskorz, P.; Komaromi, I.; Martin, R. L.; Fox, D. J.; Keith, T.; Al-Laham, M. A.; Peng, C. Y.; Nanayakkara, A.; Challacombe, M.; Gill, P. M. W.; Johnson, B.; Chen, W.; Wong, M. W.; Gonzalez, C.; Pople, J. A. Gaussian 03, revision D.01; Gaussian, Inc.: Pittsburgh, PA, 2003. All IR frequencies were checked to be positive.

(19) Imahori, H.; Hayashi, S.; Hayashi, H.; Oguro, A.; Eu, S.; Umeyama, T.; Matano, Y. J. Phvs. Chem. C 2009, 113, 18406-18413.

(20) Nazeeruddin, Md. K.; Humphry-Baker, R.; Officer, D. L.; Campbell, W. M.; Burrell, A. K.; Grätzel, M. Langmuir 2004, 20, 6514-6517.

(21) Purification of laboratory chemicals, 3rd ed.; Perrin, D. D., Armarego, W. L. F., Eds.; Pergamon Press: Oxford, 1988.

JP103561C 